\title{
The Effects of Magnetic Circuit Geometry and Material Properties on Surface Mounted Permanent Magnet Synchronous Generator Performance
}

\author{
Tuğberk Özmen and Nevzat Onat
}

\begin{abstract}
Permanent magnet synchronous generator is one of the generator types used in electrical energy production. In this study, a $1.5 \mathrm{~kW}$ inner rotor, surface located permanent magnet synchronous generator is used as a reference. The computer model of this generator has been prepared using Maxwell Rmxprt software. Rmxprt analysis of the generator has been performed and results were obtained for no-load and nominal load operating conditions. Parameters such as cogging torque which is an important parameter especially for permanent magnet synchronous generators used in wind turbines and efficiency were examined. The effects of changing in magnetic circuit as the permanent magnet pole arc to pole pitch ratio, magnet thickness and magnet material parameters on the generator performance were analyzed comparatively. Using the effects of these parameters, an optimization study has been carried out to increase the performance of the reference PMSG and compared with the values obtained in the initial state.
\end{abstract}

Index Terms-Cogging torque, efficiency, surface mounted PMSM.

\section{INTRODUCTION}

$\mathrm{P}$ ERMANENT MAGNET synchronous machines (PMSM) which have magnets in the rotor, have less copper losses, small volume and high power density, lightweight and higher efficiency compared to conventional electrical machines [1]. Thanks to their superiority, they are used in computer technologies, robotics, space technologies, electric vehicles and renewable energy systems.

Permanent magnet synchronous machines are used as generator in renewable energy conversion systems. Permanent

TUĞBERK ÖZMEN, is with Vocational School of Manisa Technical Sciences, Manisa, Turkey, (e-mail: tugberk.ozmen@ cbu.edu.tr).

\section{(iD) https://orcid.org/0000-0002-8636-6091}

NEVZAT ONAT, is with Department of Electrical and Electronics Engineering University of Manisa Celal Bayar University, Manisa, Turkey, (e-mail: nevzat.onat@cbu.edu.tr).

(iD https://orcid.org/0000-0002-2244-4441

Manuscript received October 28, 2020; accepted January 9, 2021. DOI: $\underline{10.17694 / \mathrm{bajece} .817766}$ magnet synchronous generators (PMSG) which are used especially in wind turbines can be produced in different powers and designs. PMSG can be produced in different designs. In low power applications, PMSG with surface mounted magnets can be preferred due to its easy structure and reliability [2]. PMSG does not require DC supply for excitation circuit. This eliminates the need for rings and brushes. This is an important point that provides many technical and efficiency advantages. However, it is not possible to control the air gap magnetic flux in these machines. This situation creates difficulties in voltage stability control since it means that the speed and voltage output change linearly. In addition, permanent and fixed value magnetic fields can create security problems in many processes such as montage, technical work in the field, maintenance and repair. Thermal and technical problems arise in the production and physical processing of permanent magnets. The combination of the main magnetic field created by the permanent magnets on rotor and the armature reaction field causes the excessively increasing of magnetic flux density in the air gap and the saturation on the core. In these machines, the magnetic circuit must be modeled very well at the design stage and the geometries and material properties of permanent magnets which will be used in the magnetic circuit must be optimized. As mentioned above, it is not possible to change at later of parameters which are determined at the design stage. PMSGs provide significant advantages in small power applications thanks to these features, but do not offer suitable solutions for high power systems. In addition, it has some disadvantages such as high costs and having cogging torque due to its structure.

One of the torque components of PMSG is cogging torque which occurs due to the interaction between the stator slots and the permanent magnets in the rotor under no-load operation conditions. While the cogging torque can prevent rotation of wind turbines at low speeds, it also causes noise and vibration at PMSG. Therefore, studies are carried out to eliminate the cogging torque in PMSG.

Stator design improvements [3], alternative designs of surface-mounted permanent magnet motors [4] and embedded permanent magnet motors [5] are available in the literature to 
reduce the cogging torque. The effects of magnet shape and geometries [6 and 7], of skewed and separated design of magnets [8], of using different magnet materials [9 and 10], of changing in magnet offset values [11] and magnet thickness [12] on machine performance have been investigated. The effects of magnet geometry on cost are also among the topics discussed in the literature [13]. The cogging torque is considered comparatively between the axial flux PMSM and the outer rotor PMSM [14] and between the PMSM and the induction motor [15]. Occurring errors during the manufacturing process in the stator slots of the machine, [16] and stator tooth geometries [17] affect the cogging torque. Designing the machine at a different ratio of poles/slots has an observable effect on the cogging torque [18]. Another issue examined in the literature is the effects of shifting magnets on the cogging torque of the change in the arc angle of the pole [19]. The shifting of the magnets and the change in the pole arc angle have effects on the cogging torque [19].

In this study, a $1500 \mathrm{~W}$ PMSG was used as a reference machine. The three-dimensional model of the machine was scaled and imported to the Rmxprt software. Performance of machine has been analyzed by simulating the no-load and nominal loaded operating conditions by using given label values by the manufacturer. The cogging torque and efficiency results were investigated by depending on the changes of the machine magnetic circuit. In this paper, cogging torque reducing methods has not been examined and the generator performance was examined by using only magnet structure and materials comparatively by making changes on the ratio of pole arc to pole pitch, magnet thickness and material of magnet of the reference machine.

\section{Finite Element Method}

To analyze a system as electromagnetically, the geometry is divided into finite number of small parts, the boundary conditions are defined and differential equations are written and then solved for each part. For the magnetostatic analysis in this study, ANSYS Maxwell 2D package program based on finite element method was used.

Maxwell's equations that describe how the electric and magnetic field behave are used in the background of ANSYS Maxwell software which is used in the analysis of electrical machines. An average magnetic flux density on the yoke of the stator was obtained as between $0.2 \mathrm{~T}$ and $0.9 \mathrm{~T}$ depending on the pole position in the magnetostatic analysis of the reference machine. Also, the magnetic flux density in the stator teeth is about $1.7 \mathrm{~T}$ on average.

\section{RMXPRT MODEL OF REFERENCE ELECTRICAL MACHINE}

The design parameters of the PMSG used as reference in this paper are given in Table I, and the geometrical Rmxprt model of this generator is given in Fig. 1. Stator, rotor and magnet dimensions of the reference machine given in Table I are the values obtained from the measurements made with the caliper.
TABLE I

THE DESIGN PARAMETERS OF THE PMSG

\begin{tabular}{|c|c|}
\hline Design Parameters & Values \\
\hline Nominal power & $1500 \mathrm{~W}$ \\
\hline Nominal speed & $450 \mathrm{rpm}$ \\
\hline Number of slot & 72 \\
\hline Number of poles & 16 \\
\hline Stator outer diameter & $221.5 \mathrm{~mm}$ \\
\hline Rotor outer diameter & $157.5 \mathrm{~mm}$ \\
\hline Air gap distance & $1 \mathrm{~mm}$ \\
\hline Magnet material & $\mathrm{NdFe} 35$ \\
\hline Pole arc ratio & $84.774(\%)$ \\
\hline Skew ratio & $1.5 \mathrm{~mm}$ \\
\hline Magnet thickness & $5.3196 \mathrm{~mm}$ \\
\hline Offset distance & $0 \mathrm{~mm}$ \\
\hline
\end{tabular}

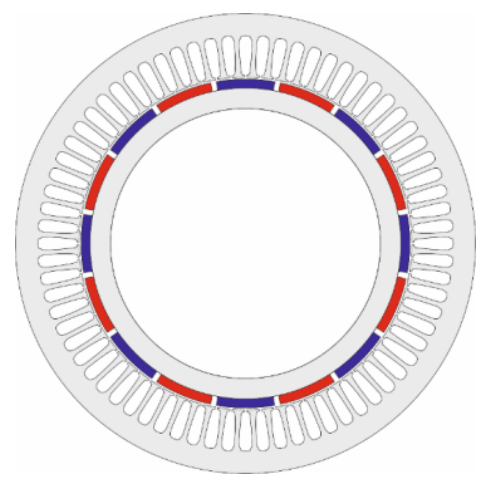

Fig.1. Slot and magnet structure of PMSG

With the Rmxprt analysis of PMSG used in this study, phase current was $12.42 \mathrm{~A}$, phase voltage $40.66 \mathrm{~V}$ and efficiency value was obtained as $87 \%$ under nominal load operating condition. The same analysis, the stator tooth flux density was found as $1.8 \mathrm{~T}$, the stator yoke flux density as 0.89 $\mathrm{T}$, the air gap flux density as $0.88 \mathrm{~T}$ and the magnet flux density as $0.93 \mathrm{~T}$ under no-loaded operating conditions.

The graph of induced voltage in the stator windings for rated load of the reference PMSG is given in Figure 2. As can be seen in this figure, the voltage wave is not pure-sinusoidal shaped and the harmonic components of this voltage wave are shown in Figure 3.

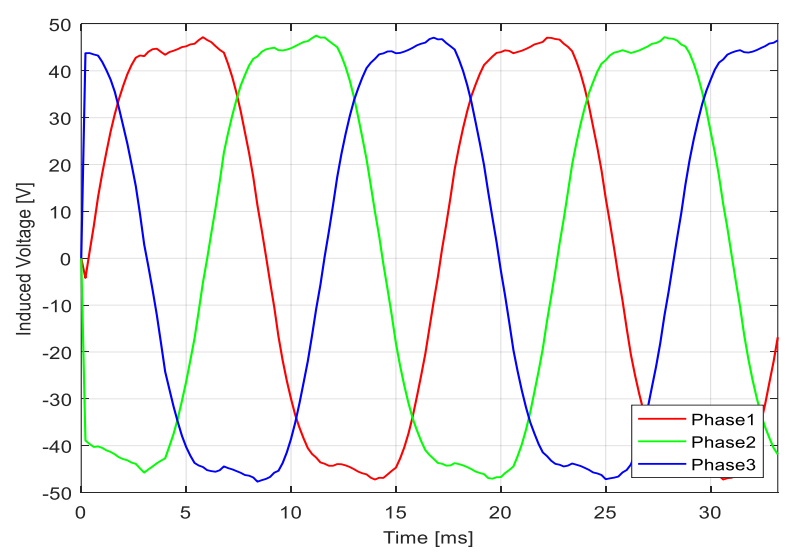

Fig.2. Induced voltage under rated-load conditions of PMSG 


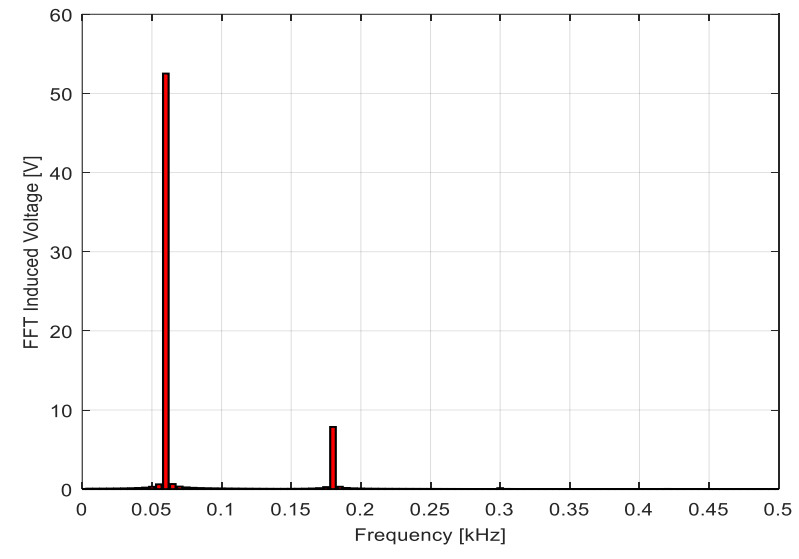

Fig.3. Harmonic spectrum of induced voltage of PMSG

\section{INVESTIGATION OF THE EFFECT OF DESIGN PARAMETERS}

In this paper, the magnetic circuit geometry and material properties of the PMSG which was used as a reference, were changed and the effects on performance were examined. Analysis results given in section 3 are obtained by using magnet pole arc ratio and magnet thickness values and magnet material as given in Table I. In this section, the generator performance is comparatively examined for the values of magnet pole arc ratio between 0.80 and 0.95 and for values of magnet thickness between $5 \mathrm{~mm}$ and $6 \mathrm{~mm}$ and for using SmCo24, $\mathrm{SmCo} 28$ and $\mathrm{NdFe} 35$ as the magnet type. The effects of the change of these parameters on the cogging torque, air gap magnetic flux density and efficiency were determined. The drawing of the rotor of the reference machine used in the paper is given in Fig.4.

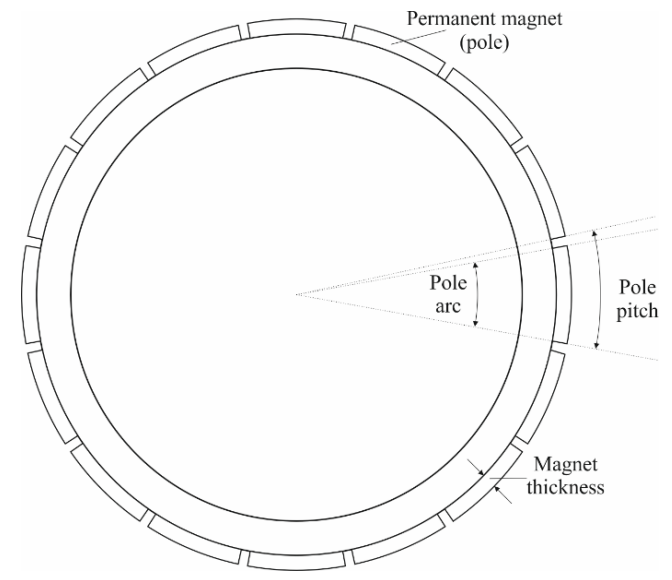

Fig.4. Detailed drawing of PMSG rotor

\section{A. Ratio of Magnet Pole Arc to Pole Pitch}

The cogging torque graph according to electrical angle obtained in the simulations made through the Rmxprt software depending on the change in the ratio of the pole arc to the pole pitch is given in Fig. 5, the air gap magnetic flux density graph is given in Fig. 6 and the numerical values found given in Table II. In the obtained results, it was observed that the increase in the ratio of pole arc to pole pitch from $80 \%$ to $95 \%$ cause an increase at the cogging torque and flux density in the air gap. Especially for $90 \%$ and $95 \%$ values of pole arc to pole pitch ratio, increasing in the cogging torque reaches very high values. The effect of the changing in pole arc to pole pitch ratio on the air gap magnetic flux density is quite limited. On the other hand, the efficiency value decreased around to $3 \%$ for pole arc to pole pitch ratio.

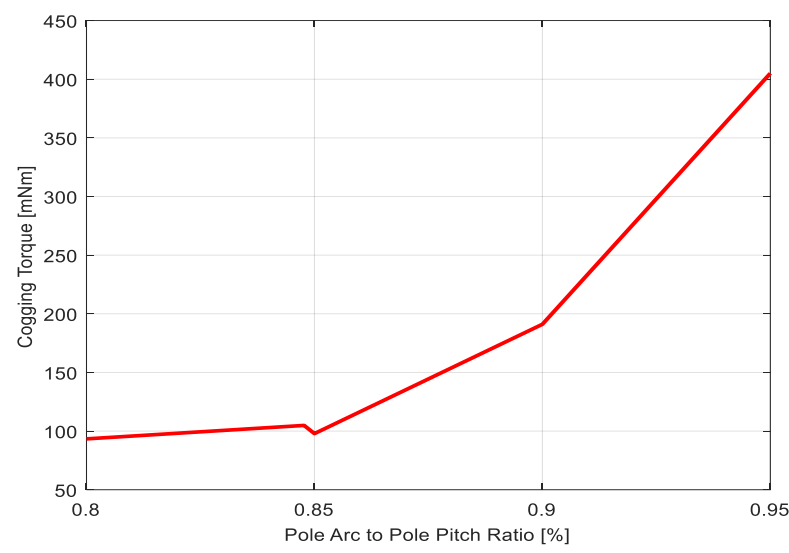

Fig.5. The effect of the change in the pole arc to pole pitch ratio on the cogging torque

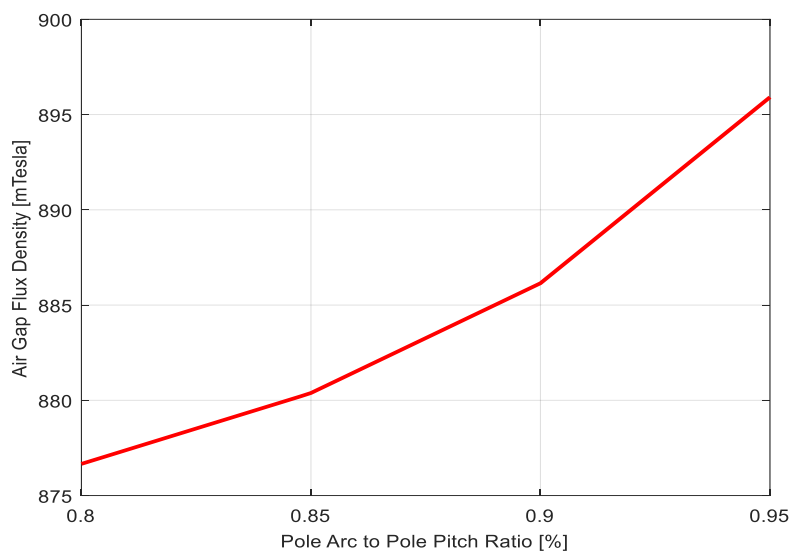

Fig.6. The effect of the change in the pole arc to pole pitch ratio on the air gap flux density

TABLE II

THE EFFECT OF THE CHANGE IN THE POLE ARC TO POLE PITCH RATIO

\begin{tabular}{|c|c|c|c|}
\hline $\begin{array}{c}\text { Pole Arc to Pole } \\
\text { Pitch Ratio (\%) }\end{array}$ & $\begin{array}{c}\text { Cogging Torque } \\
(\mathrm{Nm})\end{array}$ & $\begin{array}{c}\text { Air Gap Flux } \\
\text { Density (mT) }\end{array}$ & Efficiency (\%) \\
\hline 80,00 & 0,093 & 876,58 & 88,41 \\
\hline 84,77 & 0,104 & 880,16 & 87,43 \\
\hline 85,00 & 0,097 & 880,33 & 87,39 \\
\hline 90,00 & 0,191 & 886,11 & 86,50 \\
\hline 95,00 & 0,405 & 895,89 & 85,66 \\
\hline
\end{tabular}

\section{B. Thickness of Magnet}

In the second step, the effects of the change in magnet thickness on the PMSG performance were examined by calculations made through the Rmxprt software. The obtained results are given in Fig. 7, Fig. 8 and Table III. It has been determined that when the magnet thickness is increased gradually up to a maximum of $20 \%$, the cogging torque 
decreased 6.9\%. Despite this increase, the air gap flux density increased by $2,5 \%$. Increasing in magnet thickness creates changes $1,5 \%$ in efficiency value.

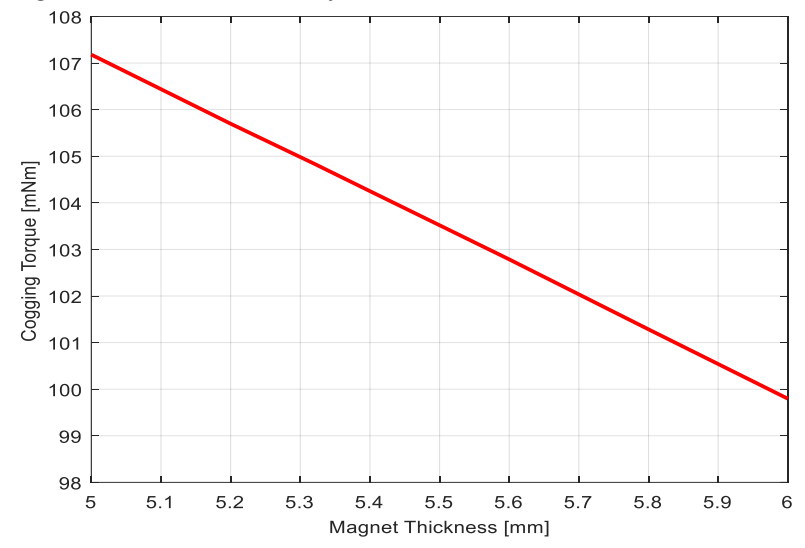

Fig.7. The effect of the change in the magnet thickness on the cogging torque

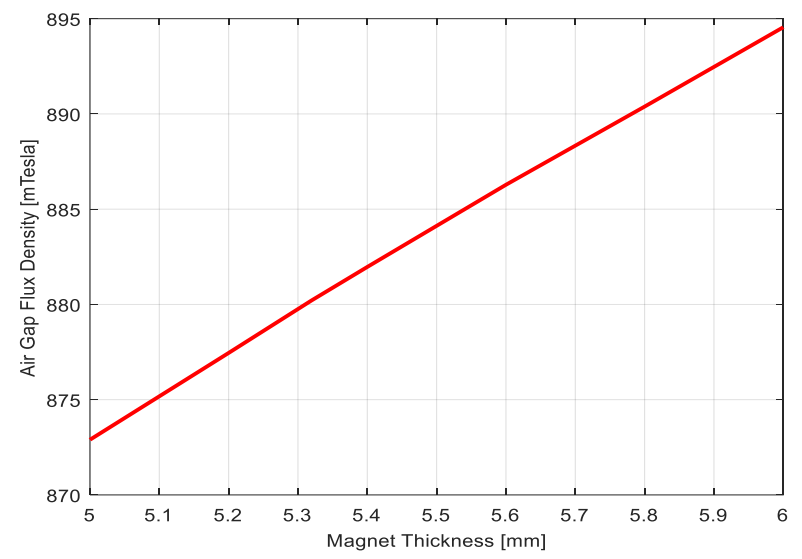

Fig.8. The effect of the change in the magnet thickness on the air gap flux density

TABLE III

THE EFFECT OF THE CHANGE IN THE MAGNET THICKNESS

\begin{tabular}{|c|c|c|c|}
\hline $\begin{array}{c}\text { Magnet Thickness } \\
(\mathrm{mm})\end{array}$ & $\begin{array}{c}\text { Cogging Torque } \\
(\mathrm{mNm})\end{array}$ & $\begin{array}{c}\text { Air Gap Flux } \\
\text { Density (mT) }\end{array}$ & Efficiency (\%) \\
\hline 5,00 & 107,18 & 872,86 & 87,95 \\
\hline 5,20 & 105,69 & 877,41 & 87,63 \\
\hline 5,3196 & 104,84 & 880,16 & 87,43 \\
\hline 5,40 & 104,25 & 881,91 & 87,31 \\
\hline 5,60 & 102,78 & 886,21 & 86,99 \\
\hline 5,80 & 101,28 & 890,3 & 86,69 \\
\hline 6,00 & 99,79 & 894,45 & 86,39 \\
\hline
\end{tabular}

\section{Magnet Material}

Different materials have been using as a permanent magnet in PMSG such as AlNiCo, NdFe, Ferrit, SmCo. There are differences of these materials between the demagnetization values, coercivity force values and the maximum values of multiplication of magnetic field strength and magnetic flux density. Therefore, the application should be considered when choosing the magnet. In this paper, effects of magnet materials on cogging torque, air gap magnetic flux density and efficiency were investigated by using $\mathrm{SmCo} 24, \mathrm{SmCo} 28$ and
$\mathrm{NdFe} 35$ magnets. In this study, $\mathrm{NdFe} 35$ and SmCo magnets were preferred because they have superior magnetic properties compared to AlNiCo and Ferrite type magnets. Used magnets' some magnetic values get from the library of ANSYS Maxwell software are given in Table IV.

TABLE IV

\begin{tabular}{|l|c|c|c|}
\multicolumn{1}{|c|}{ MAGNETIC PROPERTES OF USED MAGNET MATERIALS } \\
\hline $\begin{array}{l}\text { Relative } \\
\text { permeability }\end{array}$ & 1,099 & 1,063 & 1,038 \\
\hline $\begin{array}{l}\text { Bulk conductivity } \\
\text { (S/m) }\end{array}$ & 625.000 & 1.111 .111 & 1.111 .111 \\
\hline $\begin{array}{l}\mathrm{H} \text { magnitude } \\
(\mathrm{A} / \mathrm{m})\end{array}$ & 890.000 & 756.000 & 820.000 \\
\hline
\end{tabular}

In Fig. 9, the cogging torque curves of NdFe35, SmCo24 and $\mathrm{SmCo} 28$ are given together obtained from the calculations made over Rmxprt software. The air gap flux density curve obtained for these three types of magnets with the calculations is given in Fig. 10. The obtained results are given in Table V. $\mathrm{NdFe} 35$ provides the highest air gap flux density and the cogging torque value highest when this magnet is used. Similarly, when SmCo24 magnet is used, the cogging torque and air gap flux density values are the lowest compared to other magnet materials. From this point of view, besides some advantages of magnet materials, there are also disadvantageous parameters. In this study that three different materials discussed, changes such as $5 \%$ in efficiency, $16 \%$ in air gap flux and $34,5 \%$ in cogging torque occur. Therefore, it is important to choose the magnet material according to the functions expected from the machine.

M19-29G steel material is used as core material of the machine used as a reference in this paper. B-H curve for the material M19-29G is given in Fig. 11. This curve loses its linearity after about $1.8 \mathrm{~T}$ and the material will begin to saturate. It is necessary to design a magnetic circuit in which values below the saturation point will be obtained. For this reason, the flux distribution in the core material depending on the magnet material of the machine was also examined. Magnetic flux distribution graphs obtained as a result of magnetostatic analysis of the machine are given respectively in Fig.12, Fig.13 and Fig.14 for SmCo24, SmCo28 and NdFe35 magnets.

When the flux distributions of magnetostatic analysis are examined, the difference in the flux densities in the stator teeth is observed when only the magnet types are changed for the same machine geometry. For the same machine, when SmCo24 and SmCo28 type magnets are used, the pole thickness parameter should be increased to obtain higher efficiency and air gap flux. The magnetic flux density is higher when $\mathrm{NdFe} 35$ magnet is used. This results in an increase in efficiency and cogging torque also increases. Flux density values are below the saturation point for all three materials are used. In this respect, it can be said that the selected steel sheet model is suitable in terms of design. 


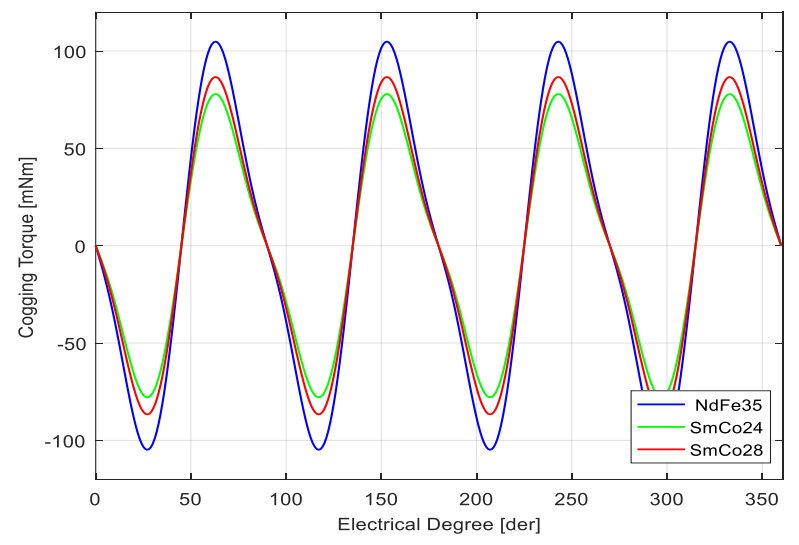

Fig.9. The effect of different magnet materials on the torque

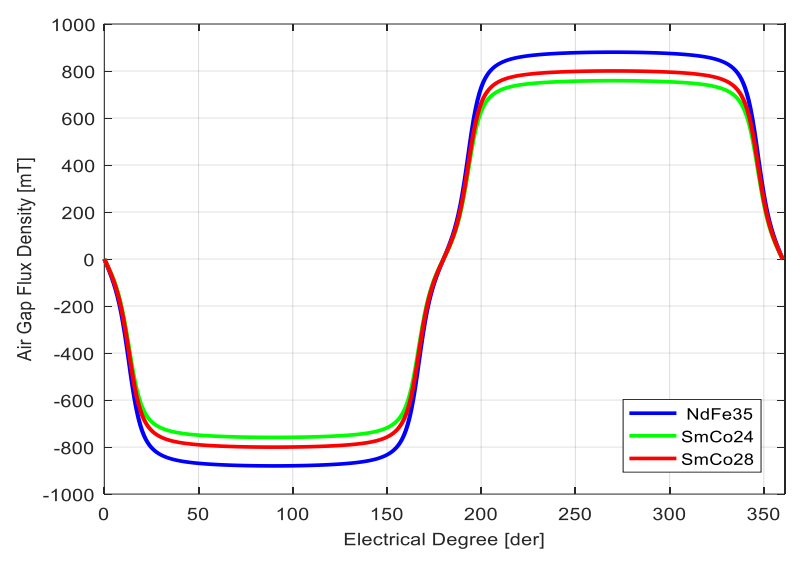

Fig 10. The effect of different magnet materials on the air gap flux density

TABLE V

THE EFFECT OF DIFFERENT MAGNET MATERIALS

\begin{tabular}{|c|c|c|c|}
\hline Magnet Material & $\begin{array}{c}\text { Cogging Torque } \\
(\mathrm{mNm})\end{array}$ & $\begin{array}{c}\text { Air Gap Flux } \\
\text { Density (mT) }\end{array}$ & Efficiency (\%) \\
\hline $\mathrm{SmCo} 24$ & 77,91 & 758,81 & 83,64 \\
\hline $\mathrm{SmCo} 28$ & 86,67 & 800,32 & 86,18 \\
\hline $\mathrm{NdFe} 35$ & 104,84 & 880,16 & 87,43 \\
\hline
\end{tabular}

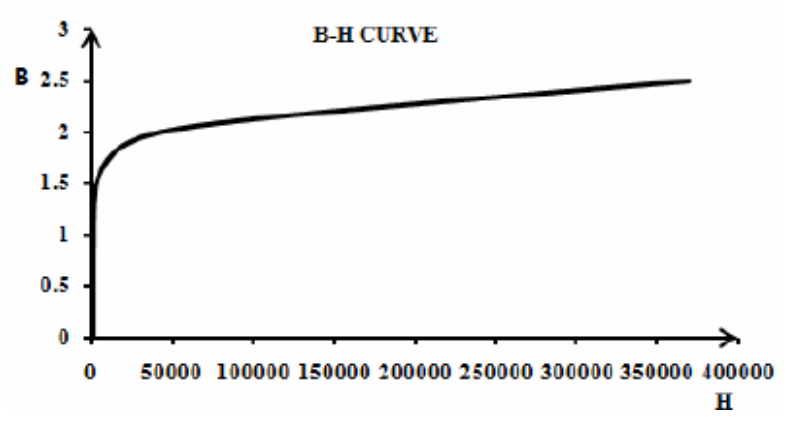

Fig 11. B-H curve of M19-29G [20]

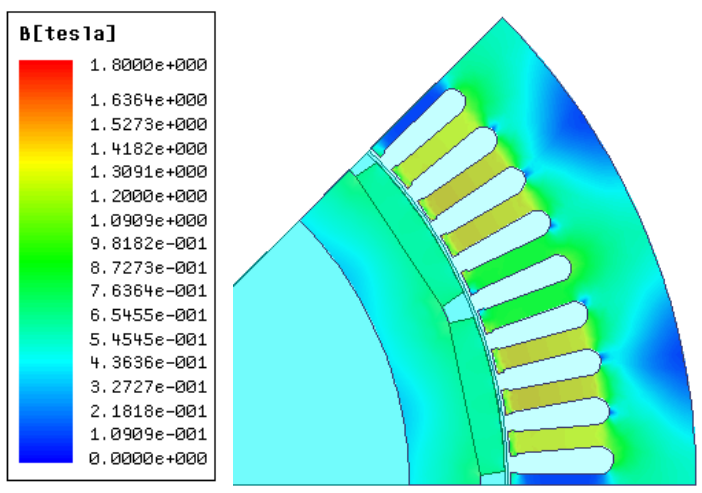

Fig.12. Flux density of magnetostatic analysis of machine when used SmCo24 magnet

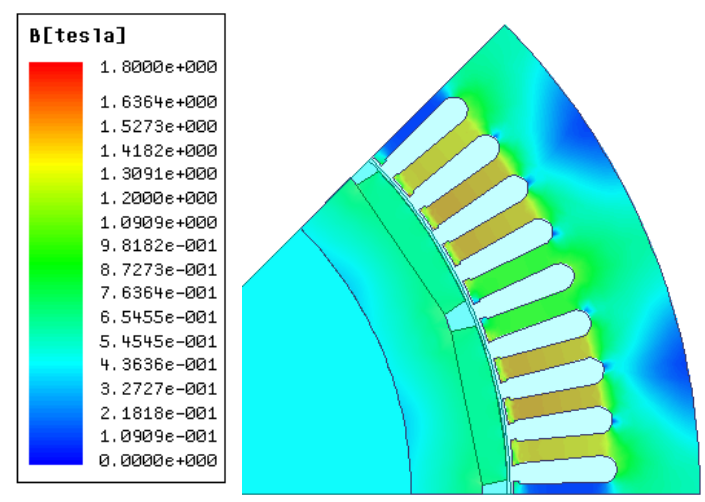

Fig.13. Flux density of magnetostatic analysis of machine when used SmCo28 magnet

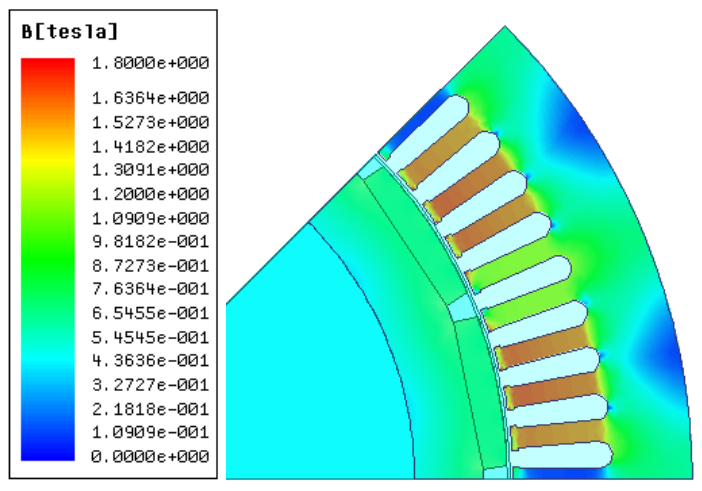

Fig.14. Flux density of magnetostatic analysis of machine when used NdFe35 magnet

In order to increase the performance of the PMSG which is used as a reference in this study, an optimization approach has been made over the examined magnetic circuit parameters. $\mathrm{NdFe} 35$ has been used as the magnet material and the magnet thickness has selected as $6 \mathrm{~mm}$ and the pole arc to pole pitch ratio has selected as 0.85 . In this case, the change in the analyzed performance parameters has given in Table VI. Thanks to the improvement, the efficiency of the PMSG was increased by $1.01 \%$, the air gap flux density was increased by $1.66 \%$ and the cogging torque was reduced by $11.59 \%$. 
TABLE VI

EFFECTS OF REFERENCE AND OPTIMIZED KMSG

\begin{tabular}{|c|c|c|}
\hline & $\begin{array}{c}\text { Reference } \\
\text { KMSG }\end{array}$ & $\begin{array}{c}\text { Optimized } \\
\text { KMSG }\end{array}$ \\
\hline $\begin{array}{c}\text { Cogging Torque } \\
\text { (mNm) }\end{array}$ & 104,84 & 92,69 \\
\hline $\begin{array}{c}\text { Air Gap Flux } \\
\text { Density (mT) }\end{array}$ & 880,16 & 894,76 \\
\hline Efficiency (\%) & 87,43 & 88,31 \\
\hline
\end{tabular}

\section{CONCLUSION}

In this paper, the effects of some design parameters such as the ratio of pole arc to pole pitch, magnet thickness and type of magnet materials, on the cogging torque, air gap flux density and efficiency of PMSG were investigated. Using the obtained results, new values of PMSG parameters have been presented for better output performance.

When the value of pole arc ratio increased from $80 \%$ to $95 \%$, the cogging torque increased from $0.093 \mathrm{Nm}$ to 0.405 $\mathrm{Nm}$. Air gap flux density value increased, and the efficiency value decreased with increasing in pole arc ratio. The increase of the pole arc ratio can be decided according to the usage purpose of the machine. In applications where high cogging torque is required, being high in this ratio may be an advantage. However, it should be taken into account that the increase in the pole arc ratio is a disadvantage in terms of energy efficiency. The increase in magnet thickness results in a decrease in the cogging torque and it caused an increase in the amount of flux in the air gap. The efficiency decreased when magnet thickness is increase. Increasing the magnet thickness does not provide an advantage in terms of general parameters. Both the cogging torque and the decrease in efficiency are remarkable in this respect. However, the effects of increasing the magnet thickness on the torque ripple may be examine in different study.

In order to examine the effects of the used magnet materials on machine performance; SmCo24, SmCo28 and NdFe35 type magnets have analyzed using on the same reference machine. In the analysis, the highest values of efficiency and air gap flux density are obtained for NdFe35 magnet, on the other hand, the cogging torque value for this magnet is obtained higher compared to other types of magnets. In the analysis, although the cogging torque value for $\mathrm{SmCo} 24$ magnet was low, efficiency and air gap flux density values were also obtained at the lowest value. As a result of the magnetostatic analysis, the magnetic flux density value in the stator teeth of PMSG was obtained as approximately $1.3 \mathrm{~T}$ when $\mathrm{SmCo} 24$ magnet was used, $1.5 \mathrm{~T}$ when $\mathrm{SmCo} 28$ magnet was used, and $1.8 \mathrm{~T}$ when $\mathrm{NdFe} 35$ magnet was used. With the optimization approach made on the magnetic circuit parameters, the cogging torque was reduced, the air gap flux density and efficiency values were increased. In the selection of the magnet by using the above results, the purpose of use of the PMSM and the expected performance, cost, etc. factors can be considered.
As a continuation of the study, the effects of the examined parameters on the PMSG performance will be examined and interpreted under loaded operating conditions and failure conditions and the results of the experiments to be made with the real machine model will be compared.

\section{REFERENCES}

[1] M. Güleç, E. Yolacan, Y. Demir, O. Ocak, M. Aydin. "Modeling based on 3D finite element analysis and experimental study of a 24-slot 8-pole axial-flux permanent-magnet synchronous motor for no cogging torque and sinusoidal back-EMF." Turkish Journal of Electrical Engineering \& Computer Sciences, vol. 24. 1, 2016, pp 262-275.

[2] H. Li, Z. Chen. "Design optimization and site matching of direct-drive permanent magnet wind power generator systems." Renewable Energy, vol. 34. 4, 2009, pp 1175-1184.

[3] D. Uygun, Y. Çetinceviz. "Yüzey yerleştirmeli kalıcı mıknatıslı senkron generatörlerin tutma torkunun azaltılması için stator yapılandırması." Gazi Üniversitesi Fen Bilimleri Dergisi Part C: Tasarım ve Teknoloji, vol. 6. 3, 2018, pp 605-620.

[4] N. Bianchi, S. Bolognani. "Design techniques for reducing the cogging torque in surface-mounted PM motors." IEEE Transactions on industry applications, vol. 38. 5, 2002, pp 1259-1265.

[5] Z. Q. Zhu, S. Ruangsinchaiwanich, N. Schofield, D. Howe. "Reduction of cogging torque in interior-magnet brushless machines." IEEE Transactions on Magnetics, vol. 39. 5, 2003, pp 3238-3240.

[6] G. C. Lee, S. H. Kam, T. U. Jung. "Design on Permanent Magnet Structure of Radial Flux Permanent Magnet Generator for Cogging Torque Reduction and Low Torque Ripple." 16th European Conference on Power Electronics and Applications, Lappeenranta, Finland, 2014.

[7] Z. Li, J. H. Chen, C. Zhang, L. Liu, X. Wang. "Cogging Torque Reduction in External-Rotor Permanent Magnet Torque Motor Based on Different Shape of Magnet." 2017 IEEE International Conference on Cybernetics and Intelligent Systems (CIS), China, 2017.

[8] A. Dalcal, E. Kurt, E. Çelik, N. Öztürk. "Cogging torque minimization using skewed and separated magnet geometries." Politeknik Dergisi, vol. 2. 3, 2020, pp 223-230.

[9] A. Dalcalı, C. Ocak. "Farklı mıknatıs malzemelerinin yüzey mıknatıslı doğrudan tahrikli sabit mıknatıslı senkron motor performansına etkisi." Journal of Awareness, vol. 3. Special, 2018, pp 217-224.

[10] H. Mamur. "Performance evaluation for a PMSG with interior rotor of N35 and N42 NdFeB PMS having same geometry in micro wind turbines." International Journal of Energy Applications and Technologies, vol. 3. 2, 2016, pp 50-54.

[11] A. N. Patel. "Cogging Torque Minimization by Magnet Edge Inset Variation Technique in Radial Flux Surface Mounted Permanent Magnet Brushless DC (PMBLDC) Motor." 5th Nirma University International Conference on Engineering (NUiCONE), Gujarat, India, 2015.

[12] B. Vidhya, K. N. Srinivas. "Effect of stator permanent magnet thickness and rotor geometry modifications on the minimization of cogging torque of a flux reversal machine." Turkish Journal of Electrical Engineering \& Computer Sciences, vol. 25. 6, 2017, pp 4907-4922.

[13] C. Ocak. "Doğrudan tahrikli asansör sistemlerinde kullanılan sabit mıknatıslı senkron motorlarda mıknatıs geometrisinin motor performansı ve maliyeti üzerindeki etkilerinin incelenmesi." Mühendislik Bilimleri ve Tasarım Dergisi, vol. 7. 4, 2019, pp 825-834.

[14] A. Aksöz, A. Saygın. "Aynı fiziksel ve elektromanyetik parametreler altında EASMSM ve ORSMSM'un vuruntu torkuna göre karşılaştırılması." Gazi Üniversitesi Fen Bilimleri Dergisi Part C: Tasarım ve Teknoloji, vol. 6. 3, 2018, pp 659-667.

[15] H. Yetiş, T. Göktaş. "Comparative design of permanent magnet synchronous motors for low-power industrial applications." Balkan Journal of Electrical and Computer Engineering, vol. 8. 3, 2020, pp 218224.

[16] E. Çetin, F. Daldaban. "Eksenel akılı motorlarda oluk açıklıklarındaki hatanın moment üzerine etkisi." El-Cezeri Fen ve Mühendislik Dergisi, vol. 4. 3, 2017, pp 374-381.

[17] A. Gündoğdu, R. Çelikel, and Ş. Fidan. "Analysis and Simulation of A Three-Phase Delta Inverter for A Star-Connected RL Load." European Journal of Technique 10.2, 2020, 274-288. 
[18] C. Ocak. "Design and performance comparison of four-pole brushless DC motors with different pole/slot combinations." The International Journal of Energy and Engineering Sciences, vol. 3. 3, 2018, pp 69-78.

[19] L. Dosiek, P. Pillay. "Cogging torque reduction in permanent magnet machines." IEEE Transactions on industry applications, vol. 43. 6, 2007, pp 1565-1571.

[20] R. Jayapragash, C. Chellamuthu. "Development of analytical models for switched reluctance machine and their validation." Journal of Electrical Engineering \& Technology, vol. 10. 3, 2015, pp 990-1001.

\section{BIOGRAPHIES}

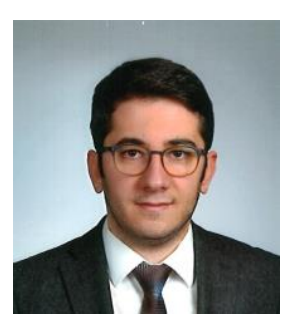

TUGBERK OZMEN graduated from department of Electrical Engineering at Istanbul Technical University, in 2015. He worked some companies in the field of renewable energies and photovoltaic power plants until 2018. He started to work in Vocational School of Manisa Technical Sciences, in 2018. His M.Sc. continues at Manisa Celal Bayar University in department of Electrical and Electronics Engineering.

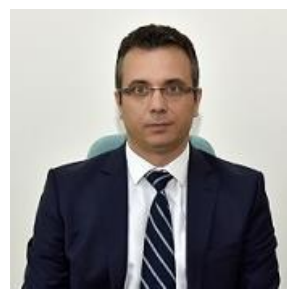

NEVZAT ONAT graduated from department of Electrical Education at Marmara University, in 1995. He received his M.Sc. and Ph.D. degrees in Electrical Education from Marmara University, Istanbul, Turkey in 1999 and 2005 respectively. He worked at Marmara University between 1997 and 2015. He has been working at Manisa Celal Bayar University since 2015. Nevzat Onat has been the Dean of Manisa Celal Bayar University Technology Faculty since 2019. His research interests include electrical machines, protection in power systems and photovoltaic systems. 